\title{
Karakterisasi fisik dan aktivitas antioksidan masker wajah gel pell off yang mengandung sari buah naga (Hylocerus polyrhizus)
}

\section{Physical characterisation and antioxidant activity of peel off gel face mask containing Hylocerus polyrhizus fruit juice}

\author{
Ririn Setiawati*, Anita Sukmawati \\ Fakultas Farmasi, Universitas Muhammadiyah Surakarta \\ *E-mail: ririnsetiawati36@gmail.com
}

\begin{abstract}
Abstrak
Kerusakan kulit yang disebabkan oleh radikal bebas dari radiasi sinar ultraviolet dapat dicegah menggunakan antioksidan. Buah naga merah (Hylocereus polyrhizus) yang mengandung antioksidan dapat dibuat menjadi masker wajah gel peel off menggunakan gelatin sebagai gelling agent untuk diaplikasikan dengan mudah pada kulit. Tujuan penelitian ini yaitu untuk menentukan pengaruh variasi konsentrasi gelatin terhadap sifat fisik dan aktivitas antioksidan masker wajah gel peel off yang mengandung sari buah naga merah. Masker wajah gel peel off dibuat dengan variasi konsentrasi gelatin 7,5\% b/b (F1); 10\% b/b (F2); dan 12,5\% b/b (F3) serta mengandung $10 \% \mathrm{~b} / \mathrm{b}$ sari buah naga merah. Masker wajah gel peel off kemudian diuji sifat fisik dan aktivitas antioksidannya dengan DPPH. Hasil menunjukkan bahwa peningkatan konsentrasi gelatin akan meningkatkan daya lekat dan mepercepat waktu mengering dari gel peel off. Peningkatan konsentrasi gelatin dari 7,5\% b/b (F1) ke 10\% b/b (F2) tidak mempengaruhi daya sebar gel peel off. Akan tetapi, daya sebar gel peel off menurun dengan meningkatnya konsentrasi gelatin dari $10 \% \mathrm{~b} / \mathrm{b}(\mathrm{F} 2) \mathrm{ke} 12,5 \% \mathrm{~b} / \mathrm{b}(\mathrm{F} 3)$. Uji aktivitas antioksidan gel peel off menghasilkan rata-rata persen penghambatan sebesar 9,101\% (F1); 12,469\% (F2); dan 15,109\% (F3). Berdasarkan hasil uji sifat fisik dan aktivitas antioksidan menunjukkan bahwa formula yang direkomendasikan yaitu formula 2.
\end{abstract}

Kata Kunci: Antioksidan, gel peel off, gelatin, Hylocereus polyrhizus.

\section{Abstract}

Damaged skin due to free radicals from ultraviolet radiation can be prevented using antioxidants. Red dragon fruit (Hylocereus polyrhizus) containing antioxidants can be made into a peel off gel face mask using gelatin as a gelling agent to be applied easily to the skin. The purpose of this study is to determine the effect of various gelatin concentrations on the physical properties and antioxidant activity of peel off gels containing red dragon fruit juice. The peel off gels face mask were made using various gelatin concentration i.e $7.5 \% \mathrm{w} / \mathrm{w}$ $(F 1) ; 10 \% \mathrm{w} / \mathrm{w}(F 2) ;$ and $12.5 \% \mathrm{w} / \mathrm{w}$ and containing $10 \% \mathrm{w} / \mathrm{w}$ red dragon fruit. The peel off gels then evaluated for physical properties and antioxidant activity using DPPH. The result showed that the increasing of the gelatin concentration would increase the drying time and adhesive ability of the peel off gels. The escalation of gelatin concentration from $7.5 \% \mathrm{w} / \mathrm{w}(F 1)$ to $10 \% \mathrm{w} / \mathrm{w}(\mathrm{F} 2)$ did not affect the spreading ability of the peel off gel. However, the spreading ability of the peel off gel decreased with the increasing concentration of gelatin from $10 \% \mathrm{w} / \mathrm{w}(\mathrm{F} 2)$ to $12.5 \% \mathrm{w} / \mathrm{w}(\mathrm{F3})$. The antioxidant test of peel off gel had an average percentage of inhibition of $9.101 \%$ (F1); $12.469 \%$ (F2); and 15.109\% (F3). Based on the results of physical properties and antioxidant activity showed that formula 2 was recomended.

Keywords: Antioxidant, gelatin, Hylocereus polyrhizus, peel off gel.

\section{PENDAHULUAN}

Radikal bebas dapat terbentuk karena adanya radiasi sinar ultraviolet (Suhartono, 2016). Paparan sinar ultraviolet (UV) secara terus menerus dapat menyebabkan kerusakan kulit seperti adanya bintik-bintik akibat pigmentasi, hilangnya elastisitas kulit, keriput, dan kulit kasar (Barel et al., 2009). Kerusakan yang terjadi akibat radikal bebas dapat dinetralisir dengan antioksidan (Percival, 1998). Antioksidan memiliki kemampuan dalam menetralkan radikal bebas dan mencegah kerusakan tubuh akibat radikal bebas dengan melengkapi adanya kekurangan elektron pada radikal bebas tersebut (Febrianti \& Wahyuningsih, 2016). Sumber antioksidan alami dapat diperoleh dari buah-buahan. Hal ini karena sebagian besar buah-buahan banyak 
mengandung senyawa vitamin $\mathrm{C}$, polifenol, dan karoten (Sikora et al., 2008). Salah satu buah yang mengandung senyawa antioksidan yaitu buah naga merah.

Hasil penelitian Rebecca et al. (2010) menunjukkan bahwa daging buah naga merah (Hylocereus polyrhizus) memiliki aktivitas penangkapan radikal bebas (EC50) sebesar 2,90 $\mathrm{mM}$ ekuivalen vitamin $\mathrm{C} / \mathrm{g}$ ekstrak kering. Selain itu, ekstrak air buah naga putih (Hylocereus undatus) memiliki antioksidan total sebesar 157,609 $\pm 0,25 \mathrm{mg} / \mathrm{L}$ (Halimoon and Hasan, 2010). Daging buah naga merah yang mengandung antioksidan dapat dibuat menjadi suatu sediaan kosmetik. Beberapa sediaan kosmetik yang bisa diaplikasikan untuk kulit wajah yaitu losion, krim, dan masker wajah atau masker peel off (Grace et al., 2015).

Masker wajah gel peel off merupakan masker wajah dalam bentuk gel yang praktis untuk digunakan karena setelah sediaan mengering dapat diangkat secara langsung dari kulit wajah (Syarifah et al., 2015). Selain itu, masker wajah gel peel off menyegarkan, membersihkan, melembabkan, dan merelaksasi otot-otot wajah (Sulastri \& Chaerunnisa, 2017). Masker peel off dapat digunakan untuk memperbaiki masalah kulit seperti keriput, jerawat, dan bisa juga untuk menutup pori-pori yang membesar (Grace et al., 2015). Hal ini menjadikan masker wajah gel peel off menjadi lebih unggul dari sediaan masker wajah pada umumnya (Rahmawanty et al., 2015). Masker peel off yang baik memiliki waktu kering antara 5-30 menit (Grace et al., 2015), pH antara 4,5-6,5 (Rahmawanty et al., 2015), daya sebar $5-7 \mathrm{~cm}$, dan daya lekat lebih dari 4 detik (Voigt, 1995). Penelitian ini menggunakan gelatin sebagai film forming agent dan gelling agent (Rowe et al., 2009). Konsentrasi gelatin dalam pembuatan sediaan masker wajah gel peel off mempengaruhi sifat fisik dari sediaan tersebut (Rahmawanty et al., 2015). Penelitian yang telah dilakukan Suhery and Anggraini (2016), menunjukkan bahwa masker wajah gel peel off dengan basis gelatin $30 \%$ memiliki aktivitas antioksidan dengan persen penghambatannya sebesar 63,13\%. Berdasarkan uraian di atas, maka perlu dilakukan penelitian pengaruh variasi konsentrasi gelatin terhadap sifat fisik dan aktivitas antioksidan sediaan masker wajah gel peel off dari sari buah naga merah (Hylocereus polyrhizus).

\section{METODE PENELITIAN}

\section{Alat}

Neraca analitik (Scout Pro OHAUS), alat-alat gelas (Pyrex), blender, freeze dryer (Alpha 1-2 LD Plus), pH meter (STARTER 3100), ELISA reader (Elx800 Bio Tech), sentrifuge (Plc Series), mikropipet (Socorex), Spektrofotometer UV-Vis (Genesys 10s UVVis).

\section{Bahan}

Buah naga merah (Colomadu, Karanganyar, Jawa Tengah), akuades (Mitra Medika), etanol 96\% (teknis, Mitra Medika), nipagin (teknis, Mitra Medika), blue tips, yellow tips (Multi Lab), vitamin C (E.Merck), metanol pro analisis (Merck, pharmaceutical grade, Kurnia), microplate 96 well (General Labora), polyvinyl alcohol (PVA teknis, Agung Jaya), propilen glikol (Agung jaya), gelatin (Saba Kimia), DPPH (1,1-difenil-2pikrilhidrazil) (Sigma Co).

\section{Pembuatan Sari Buah Naga Merah}

Buah naga merah (Hylocereus polyrhizus) diperoleh dari toko buah di Colomadu, Karanganyar, Jawa Tengah. Sebanyak $2 \mathrm{~kg}$ buah naga merah dicuci, dipotong, diambil daging buah beserta isinya, dan diblender selama 1 menit. Hasil blender disaring dengan kain putih agar bijinya terpisah. Hasil saringan ditimbang dan didapatkan bobot sebesar 449,72 gram (berat basah). Setelah itu, sari buah naga merah dimasukkan ke dalam toples, disimpan dalam refrigerator selama 2 hari, dan dilakukan freeze dry selama 1 hari. Hasil freeze dry ditimbang dan didapatkan berat kering sebesar 53,35 gram. 
Tabel 1. Formula sediaan masker wajah gel peel off tanpa sari buah naga merah dan dengan sari buah naga merah

\begin{tabular}{lcccccccl}
\hline \multicolumn{1}{c}{ Bahan } & Satuan & F1 & F2 & F3 & FK1 & FK2 & FK3 & Fungsi Bahan \\
\hline Gelatin & $\mathrm{g}$ & 1,5 & 2 & 2,5 & 1,5 & 2 & 2,5 & $\begin{array}{l}\text { Film forming agent dan } \\
\text { gelling agent }\end{array}$ \\
& & & & & & & & $\begin{array}{l}\text { Film forming agent } \\
\text { PVA }\end{array}$ \\
Propilen glikol & $\mathrm{g}$ & 2 & 2 & 2 & 2 & 2 & 2 & Emollient \\
Sari buah naga & $\mathrm{g}$ & 2 & 2 & 2 & 2 & 2 & 2 & Antioksidan \\
merah & 2 & 2 & 2 & - & - & - & \\
Nipagin & $\mathrm{mg}$ & 40 & 40 & 40 & 40 & 40 & 40 & Pengawet \\
Etanol 96\% & $\mathrm{g}$ & 2,5 & 2,5 & 2,5 & 2,5 & 2,5 & 2,5 & Pelarut nipagin \\
Akuades sampai & $\mathrm{g}$ & 20 & 20 & 20 & 20 & 20 & 20 & pelarut \\
\hline
\end{tabular}

Keterangan: F1=Formula 1, F2=Formula 2, F3=Formula 3, FK1: Formula kontrol 1 dengan konsentrasi gelatin 7,5\% b/b, FK2: formula kontrol 2 dengan konsentrasi gelatin 10\% b/b, FK3: formula kontrol 3 dengan konsentrasi gelatin $12,5 \% \mathrm{~b} / \mathrm{b}$.

\section{Pembuatan Sediaan Masker Wajah Gel Peel Off dari Sari Buah Naga Merah}

Formula sediaan masker wajah gel peel off tanpa sari buah naga merah dan dengan sari buah naga merah dapat dilihat pada Tabel 1. Sediaan masker wajah gel peel off dengan konsentrasi gelatin 7,5\% b/b (F1), 10\% b/b (F2) dan $12,5 \%$ b/b (F3) dibuat dengan cara melarutkan berturut turut gelatin sebanyak 1,$5 ; 2$; dan 2,5 gram gelatin dalam $4 \mathrm{~g}$ aquadest pada suhu $60^{\circ} \mathrm{C}$ di dalam beaker glass sambil diaduk. Sebanyak 2 g PVA dikembangkan dengan $8 \mathrm{~mL}$ aquadest pada suhu $80^{\circ} \mathrm{C}$ di dalam cawan porselin sambil diaduk. PVA dan gelatin dimasukkan ke dalam mortir dan dicampurkan sampai homogen (Campuran A). Sebanyak $2 \mathrm{~g}$ propilen glikol dicampurkan dengan campuran A dan diaduk sampai homogen (Campuran B). Sari buah naga merah sebanyak $2 \mathrm{~g}$ dilarutkan dengan $3 \mathrm{~g}$ aquadest di dalam beaker glass dan dicampurkan ke dalam campuran B (campuran C). Sebanyak $40 \mathrm{mg}$ nipagin dilarutkan dengan 2,5 g etanol 96\% di dalam beaker glass (campuran D). Campuran D dicampurkan ke dalam campuran $\mathrm{C}$ dan digerus sampai homogen, kemudian diaduk, dan masing-masing formula ditambahkan aquadest sampai $20 \mathrm{~g}$.

Pengujian sifat fisik sediaan masker wajah gel peel off
Pengujian sifat fisik sediaan meliputi uji organoleptis, $\mathrm{pH}$, waktu mengering, daya sebar, dan daya lekat.

\section{Pengujian secara organoleptis}

Uji secara organoleptis dilakukan dengan melihat warna, bentuk, dan mencium bau sediaan masker wajah gel peel off.

\section{Pengujian pH (derajat keasaman)}

$\mathrm{pH}$ meter dikalibrasi dengan $\mathrm{pH} 7$ dan $\mathrm{pH}$ 4. Elektroda $\mathrm{pH}$ meter dicelupkan ke dalam $500 \mathrm{mg}$ sediaan masker wajah gel peel off yang dilarutkan dengan $50 \mathrm{~mL}$ aquadest. $\mathrm{pH}$ yang telah ditampilkan di layar $\mathrm{pH}$ meter dicatat nilainya. Replikasi dilakukan sebanyak 3 kali pada masing-masing formula.

\section{Pengujian waktu mengering}

Sebanyak $500 \mathrm{mg}$ sediaan masker wajah gel peel off dioleskan pada lengan seorang perempuan dengan luas $5 \times 5 \mathrm{~cm}$ dan dihitung waktu yang dibutuhkan sediaan untuk mengering sehingga dapat dikelupas. Replikasi dilakukan sebanyak 3 kali pada masing-masing formula.

\section{Pengujian daya sebar}

Ditimbang sediaan masker wajah gel peel off sebanyak $500 \mathrm{mg}$ dan diletakkan di atas cawan petri yang telah ditempeli kertas milimeter blok pada sisi dalam. Setelah itu ditutup dengan cawan petri lain dan diberi pemberat di atas cawan petri tersebut dengan beban 0, 50, 100, dan 150 gram. Pengukuran diameter dilakukan setelah diberi pemberat 
selama 1 menit. Replikasi dilakukan sebanyak 3 kali pada masing-masing formula.

\section{Pengujian daya lekat}

Sebanyak $500 \mathrm{mg}$ sampel diletakkan di atas gelas objek dan ditutup dengan gelas obyek lain. Lalu ditekan dengan beban $1 \mathrm{~kg}$ selama 5 menit. Gelas obyek dipasang pada alat uji daya lekat yang diberi beban 80 gram. Waktu melepasnya sediaan dari gelas obyek dicatat. Replikasi dilakukan sebanyak 3 kali pada masing-masing formula.

\section{Pengujian Aktivitas Antioksidan}

Sebanyak 19,7 mg DPPH dilarutkan dalam $250 \mathrm{~mL}$ metanol pro analisis sehingga didapatkan konsentrasi 0,078 mg/mL (Prieto, 2012). Larutan tersebut dibaca absorbansinya dengan spektrofotometer UV-Vis pada panjang gelombang 400-600 nm. Panjang gelombang yang didapatkan sebesar $528 \mathrm{~nm}$ dengan pembacaan menggunakan spektrofotomoter UV-Vis, tetapi dalam penelitian ini digunakan panjang gelombang $550 \mathrm{~nm}$ karena disesuaikan dengan panjang gelombang yang ada di elisa reader.

Sediaan masker wajah gel peel off dengan konsentrasi gelatin 7,$5 ; 10$; dan $12,5 \%$ b/b diukur aktivitas antioksidannya dengan metode DPPH. Preparasi larutan yang akan diukur meliputi; kontrol (metanol pro analisis), DPPH 0,078 mg/mL, kontrol positif (vitamin C $100 \mu \mathrm{g} / \mathrm{mL}$ ), dan sampel 100 $\mathrm{mg} / \mathrm{mL}$ yang mengandung $10 \% \mathrm{~b} / \mathrm{b}$ sari buah naga merah (larutan gel peel off dengan konsentrasi gelatin 7,5\% b/b (F1); 10\% b/b (F2); dan 12,5\% b/b (F3)). larutan uji dimasukkan ke dalam wellplate 96, dibungkus dengan aluminium foil dan diinkubasi. Pembacaan absorbansi dilakukan pada inkubasi 30 menit dengan menggunakan elisa reader pada panjang gelombang $550 \mathrm{~nm}$.

\section{HASIL DAN PEMBAHASAN}

Rendemen sari buah naga merah yang didapatkan sebesar $11,86 \%$. Hasilnya berupa sari buah naga merah yang kering, berwarna merah, jika terkena udara menjadi lembek, dan berbau khas buah naga merah.
Evaluasi sifat fisik sediaan masker wajah gel peel off bertujuan untuk mengetahui pengaruh variasi konsentrasi gelatin terhadap sifat fisik sediaan yang meliputi uji organoleptis, uji $\mathrm{pH}$, uji waktu mengering, uji daya sebar, dan uji daya lekat.

Uji organoleptis bertujuan untuk mengetahui warna, bentuk dan bau sediaan masker wajah gel peel off. Hasil uji organoleptis menunjukkan bahwa pada formula 1, 2, dan 3 berwarna merah. Warna merah dihasilkan dari sari buah naga merah yang berfungsi sebagai antioksidan. Formula 1 berbentuk agak cair, formula 2 dan 3 berbentuk semi padat. Bau pada semua formula yaitu berbau khas buah naga merah.

Uji $\mathrm{pH}$ dilakukan untuk mengetahui keamanan dari suatu sediaan masker wajah gel peel off. pH sediaan masker wajah gel peel off dengan sari buah naga merah dapat dilihat pada Error! Reference source not found..

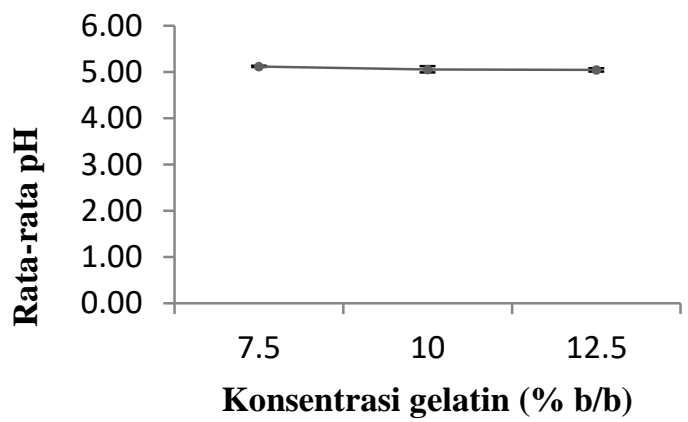

Gambar 1. Grafik hubungan antara konsentrasi gelatin dan rata-rata $\mathrm{pH}$ gel peel off dengan $10 \% \mathrm{~b} / \mathrm{b}$ sari buah naga merah. Data diambil dari rata-rata $\mathrm{pH}$ gel peel off yang diukur sebanyak 3 kali replikasi.

Hasil uji pH pada semua konsentrasi berkisar antara 5,05-5,12. Derajat keasaman $(\mathrm{pH})$ yang baik untuk sediaan masker wajah gel peel off yaitu antara 4,5-6,5 (Zhelsiana et al., 2016). Nilai $\mathrm{pH}$ tidak boleh bersifat terlalu asam karena bisa menyebabkan kulit mengalami iritasi dan tidak boleh bersifat terlalu basa karena bisa menjadikan kulit bersisik. Hasil menunjukkan semua konsentrasi gelatin memenuhi $\mathrm{pH}$ yang baik bagi kulit wajah. Gelatin bersifat asam dengan $\mathrm{pH}$ antara 3,8- 
5,5 (Rowe et al., 2009) sehingga peningkatan konsentrasi gelatin akan berpengaruh terhadap $\mathrm{pH}$ sediaan masker wajah gel peel off (Rahmawanty et al., 2015). Uji ANOVA menghasilkan nilai $\mathrm{P}$ sebesar $0,17(\mathrm{P}>0,05)$ sehingga peningkatan konsentrasi gelatin dari $7,5 \%$ b/b (F1) sampai 12,5\% b/b (F3) tidak berpengaruh terhadap $\mathrm{pH}$ sediaan masker wajah gel peel off dari sari buah naga merah. Hal ini karena perbedaan konsentrasi gelatin sebesar $2,5 \% \mathrm{~b} / \mathrm{b}$ pada masing-masing formula memiliki nilai $\mathrm{pH}$ yang tidak berbeda bermakna.

Uji waktu mengering dilakukan untuk mengetahui berapa lamanya sediaan masker wajah gel peel off dapat mengering pada saat diaplikasikan di permukaan kulit. Hasil uji waktu mengering sediaan masker wajah gel peel off dapat dilihat pada Error! Reference source not found..

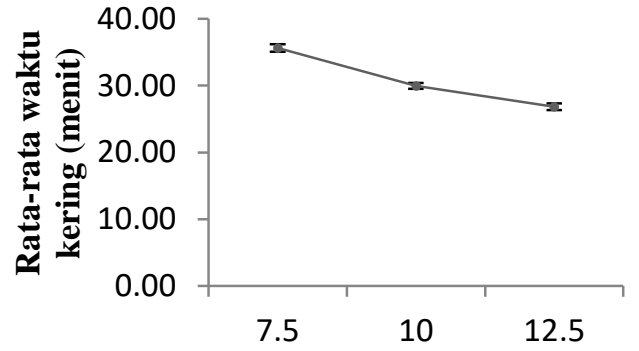

Konsentrasi gelatin $(\% \mathrm{~b} / \mathrm{b})$

Gambar 2. Grafik hubungan antara konsentrasi gelatin dan rata-rata waktu mengering gel peel off dengan $10 \% \mathrm{~b} / \mathrm{b}$ sari buah naga merah. Data diambil dari rata-rata waktu kering gel peel off yang diukur sebanyak 3 kali replikasi.

Hasil uji waktu mengering menunjukkan bahwa semakin tinggi konsentrasi gelatin, maka waktu keringnya semakin cepat. Hal ini sesuai dengan penelitian Rahmawanty et al. (2015) yang menyatakan bahwa peningkatan konsentrasi gelatin menyebabkan semakin cepatnya sediaan untuk mengering. Waktu kering yang ideal untuk sediaan masker peel off yaitu antara 15-30 menit (Grace et al., 2015). Waktu kering gel peel off pada konsentrasi gelatin $7,5 \% \mathrm{~b} / \mathrm{b} \quad(\mathrm{F} 1)$ tidak memenuhi waktu kering yang ideal. Hal ini karena terlalu rendahnya konsentrasi gelatin sehingga sediaan lebih encer. Uji ANOVA dan uji $\mathrm{t}$ menghasilkan nilai $\mathrm{P}$ sebesar 0,00 $(\mathrm{P}<0,05)$, sehingga peningkatan konsentrasi gelatin dari $7,5 \% \mathrm{~b} / \mathrm{b}$ (F1) sampai $12,5 \% \mathrm{~b} / \mathrm{b}$ (F3) dapat mempercepat waktu mengering karena gelatin berfungsi sebagai film forming agent (Rowe et al., 2009), dengan demikian semakin tinggi konsentrasi gelatin maka pembentukan film menjadi semakin cepat yang mengakibatkan sediaan gel peel off lebih cepat mengering dan mudah dilepaskan dari kulit.

Uji daya sebar bertujuan untuk mengetahui diameter penyebaran sediaan masker wajah gel peel off saat dioleskan pada kulit. Hasil uji daya sebar dapat dilihat pada Gambar 3.

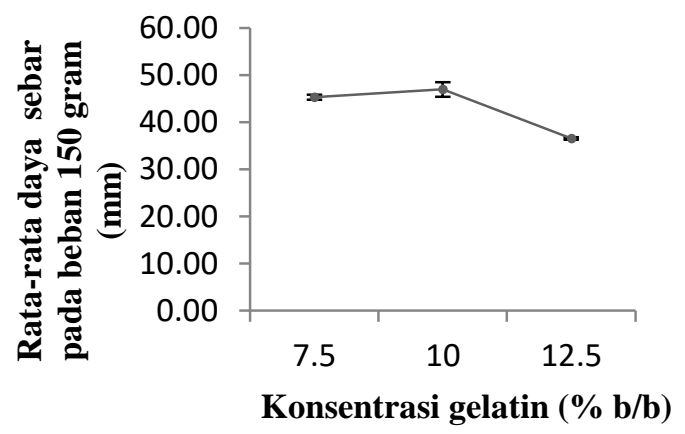

Gambar 3. Grafik hubungan antara konsentrasi gelatin dan rata-rata daya sebar gel peel off dengan $10 \%$ sari buah naga merah pada beban 150 gram. Data diambil dari rata-rata daya sebar gel peel off yang diukur sebanyak 3 kali replikasi.

Sediaan masker wajah gel peel off yang baik memiliki daya sebar 50-70 mm (Lieberman et al., 1998). Hal ini menunjukkan bahwa daya sebar pada semua konsentrasi gelatin hasilnya kurang baik karena daya sebarnya kurang dari $50 \mathrm{~mm}$. Selain itu, hasil tersebut tidak sesuai dengan penelitian Rahmawanty et al. (2015) yang menyatakan bahwa konsentrasi gelatin yang semakin tinggi dapat menurunkan daya sebar. Uji ANOVA menghasilkan nilai $\mathrm{P}$ sebesar 0,00 $(\mathrm{P}<0,05)$. Uji t antara F1 (gelatin $7,5 \% \mathrm{~b} / \mathrm{b}$ ) dengan $\mathrm{F} 2$ (gelatin $10 \% \mathrm{~b} / \mathrm{b}$ ), menghasilkan nilai $\mathrm{P}$ sebesar $0,15(\mathrm{P}>0,05)$, sehingga peningkatan konsentrasi gelatin dari konsentrasi $7,5 \%$ b/b ke $10 \%$ b/b tidak 
mempengaruhi nilai daya sebar masker wajah gel peel off. Uji t antara F1 (gelatin 7,5\% b/b) dengan F3 (gelatin $12,5 \% \mathrm{~b} / \mathrm{b}$ ) serta $\mathrm{F} 2$ (gelatin $10 \% \mathrm{~b} / \mathrm{b}$ ) dengan $\mathrm{F} 3$ (gelatin $12,5 \%$ $\mathrm{b} / \mathrm{b})$, menghasilkan nilai $\mathrm{P}$ sebesar 0,00 $(\mathrm{P}<0,05)$, sehingga peningkatan konsentrasi gelatin dari konsentrasi $10 \%$ b/b (F2) ke $12,5 \% \mathrm{~b} / \mathrm{b} \quad(\mathrm{F} 3)$ menurunkan daya sebar masker wajah gel peel off. Hal ini disebabkan karena gel peel off dengan konsentrasi gelatin $12,5 \% \mathrm{~b} / \mathrm{b}$ (F3) memiliki konsistensi yang lebih kental sehingga daya sebarnya semakin rendah.

Uji daya lekat bertujuan untuk mengetahui seberapa besar kemampuan gel melekat pada permukaan kulit dalam jangka waktu tertentu sehingga dapat berfungsi secara maksimal. Hasil uji daya lekat dapat dilihat pada Error! Reference source not found.

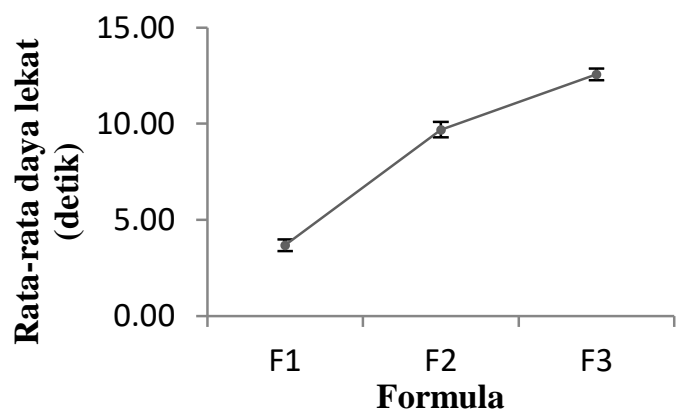

Gambar 4. Grafik hubungan antara konsentrasi gelatin dan daya lekat gel peel off dengan $10 \%$ sari buah naga merah. Data diambil dari rata-rata daya lekat gel peel off yang diukur sebanyak 3 kali replikasi.

Hasil uji daya lekat menunjukkan bahwa semakin tinggi konsentrasi gelatin maka daya lekatnya semakin meningkat. Hal ini sesuai dengan penelitian Rahmawanty et al., (2015) yang menyebutkan bahwa peningkatan konsentrasi gelatin mengakibatkan peningkatan daya lekat karena konsistensi sediaan yang meningkat. Daya lekat yang baik untuk sediaan masker wajah gel peel off yaitu lebih dari 4 detik (Voigt, 1995). Hasil penelitian menunjukkan bahwa masker wajah gel peel off dengan $10 \% \mathrm{~b} / \mathrm{b}$ sari buah naga merah pada konsentrasi gelatin $7,5 \%$ b/b (F1) tidak memenuhi syarat. Uji ANOVA dan uji t menghasilkan nilai $\mathrm{P}$ sebesar $0,00(\mathrm{P}<0,05)$, sehingga peningkatan konsentrasi gelatin dari $7,5 \%$ b/b (F1) sampai $12,5 \%$ b/b (F3) meningkatkan daya lekat sediaan masker wajah gel peel off dari sari buah naga merah. Hal ini berkaitan dengan konsistensi sediaan karena semakin tinggi konsentrasi gelatin maka konsistensi sediaan gel peel off menjadi lebih kental sehingga daya lekatnya menjadi tinggi.

Hasil pengujian aktivitas antioksidan pada sediaan kontrol (tanpa sari buah naga merah) dengan konsentrasi gelatin $7,5 \% \mathrm{~b} / \mathrm{b}$ (FK1), 10\% b/b (FK2), dan 12,5\% b/b (FK3) tidak menunjukkan adanya reaksi penghambatan radikal DPPH setelah inkubasi 30 menit karena tidak terjadi perubahan warna (Gambar 5). Hal tersebut menunjukkan bahwa basis gel (gelatin) yang digunakan dalam pembuatan masker wajah gel peel off tidak memiliki aktivitas antioksidan.

Pengenceran bertingkat dilakukan untuk mengetahui konsentrasi sari buah naga merah yang sudah tidak berwarna. Jika sampel sudah memiliki warna merah kemudian ditambahkan DPPH yang memiliki warna ungu, maka nilai absorbansinya menjadi bias ketika dibaca di spektrofotometer visible. Hal ini karena buah naga merah dan DPPH memiliki panjang gelombang maksimal yang hampir sama. Buah naga merah memiliki panjang gelombang maksimal sebesar $536 \mathrm{~nm}$ dan DPPH memiliki panjang gelombang maksimal sebesar $528 \mathrm{~nm}$. Sebenarnya sampel yang berwarna dapat diuji aktivitas antioksidan dengan syarat sampel tersebut harus diencerkan sampai warna pada sampel tersebut tidak tampak. Dalam penelitian ini, untuk konsentrasi sampel sari buah naga merah $10 \mathrm{mg} / \mathrm{mL} ; 5 \mathrm{mg} / \mathrm{mL} ; 2,5 \mathrm{mg} / \mathrm{mL}$; dan $1,25 \mathrm{mg} / \mathrm{mL}$, warna merah sudah tidak terlihat sehingga data tersebut dapat diterima.

Grafik hubungan antara konsentrasi sari buah naga merah dengan persen penghambatan dapat dilihat pada Error! Reference source not found.. Berdasarkan Gambar 5, dapat dilihat bahwa nilai persen 


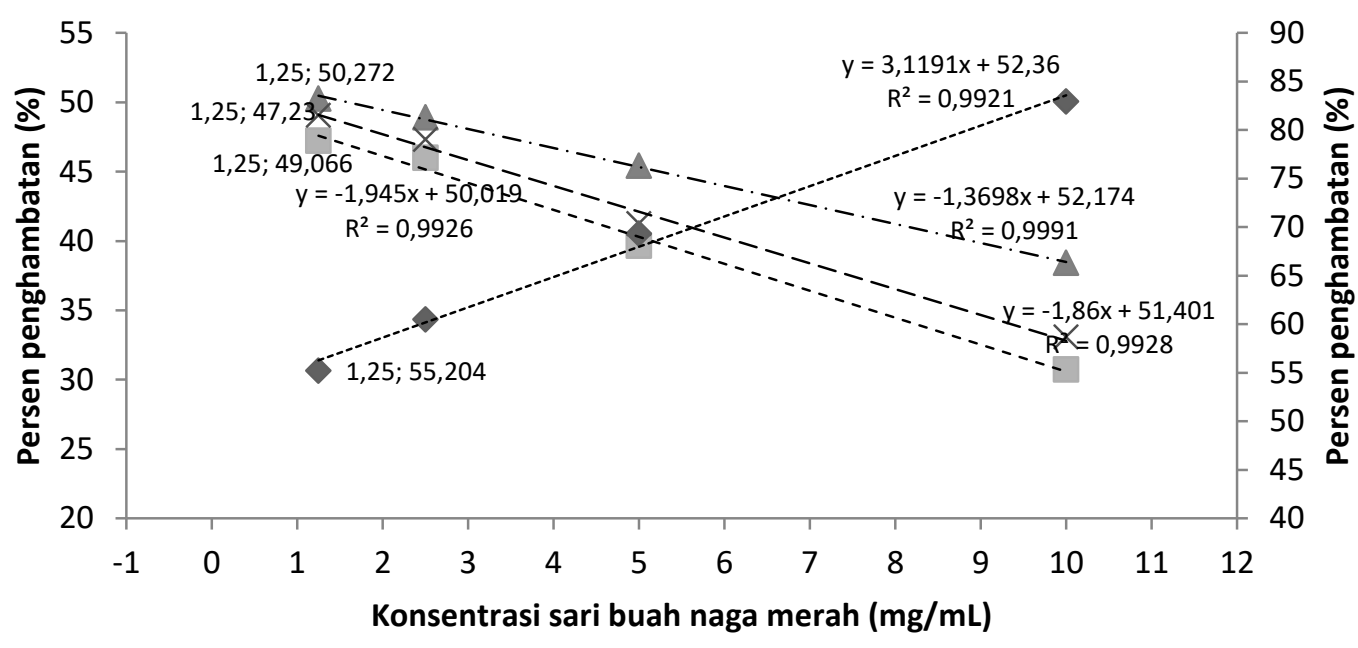

Formula $1 \triangle$ Formula $2 \times$ Formula $3 \triangleleft$ Sari Buah

Gambar 5. Grafik hubungan antara konsentrasi sari buah naga merah dengan persen penghambatan sari buah naga merah dan masker wajah gel peel off pada formula 1, 2, dan 3.

penghambatan sari buah naga merah lebih tinggi dibandingkan dengan nilai persen penghambatan sari buah naga merah yang sudah dimasukkan ke dalam sediaan masker wajah gel peel off. Hal ini dikarenakan pada gel peel off terdapat gelling agent gelatin dan film forming agent PVA sehingga pelepasan aktivitas antioksidan terhalang oleh kedua bahan tersebut. Penelitian ini menguji aktivitas antioksidan pada inkubasi 30 menit, 1 jam, 2 jam, dan 24 jam, tetapi yang dipilih yaitu inkubasi 30 menit karena sediaan masker wajah gel peel off efektif digunakan selama 30 menit. Nilai $\mathrm{IC}_{50}$ sari buah naga merah tidak bisa didapatkan karena konsentrasi sampel terkecil $(1,25 \mathrm{mg} / \mathrm{mL})$ sudah memberikan persen penghambatan lebih dari $50 \%$, sehingga perlu ditambahkan pengujian pada konsentrasi dibawah 1,25 mg/mL.

Hubungan antara formula masker wajah gel peel off yang mengandung $10 \% \mathrm{~b} / \mathrm{b}$ sari buah naga merah dengan rata-rata persen penghambatan dapat dilihat pada Gambar 6. Berdasarkan Gambar 6 menunjukkan bahwa pada F1 (gelatin 7,5\% b/b), F2 (gelatin 10\% b/b), dan F3 (gelatin 12,5\% b/b) menghasilkan rata-rata persen penghambatan sebesar 9,101\% (F1); 12,469\% (F2); dan 15,109\%
(F3). Uji ANOVA dan uji t menghasilkan nilai $\mathrm{P} \quad$ sebesar $0,00 \quad(\mathrm{P}<0,05)$, sehingga peningkatan konsentrasi gelatin dari $7,5 \% \mathrm{~b} / \mathrm{b}$ sampai $12,5 \% \mathrm{~b} / \mathrm{b}$ meningkatkan aktivitas antioksidan masker wajah gel peel off. Hal ini sesuai dengan penelitian Naibaho et al., (2016) yang menyatakan bahwa semakin meningkatnya konsentrasi gelatin maka kadar vitamin $\mathrm{C}$ akan semakin meningkat, sehingga aktivitas antioksidannya juga meningkat.

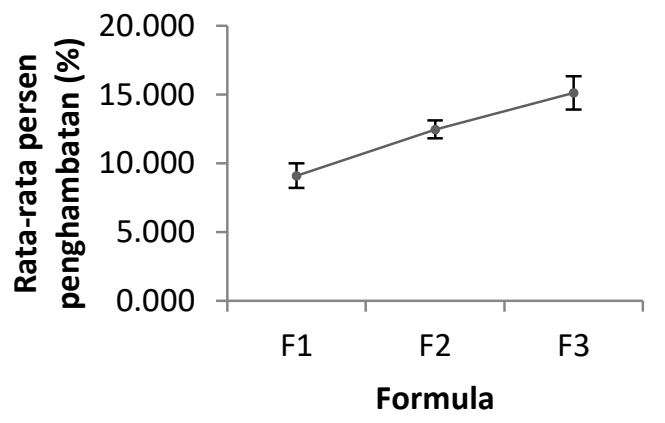

Gambar 6. Grafik hubungan antara formula masker wajah gel peel off pada konsentrasi 100 $\mathrm{mg} / \mathrm{mL}$ dengan rata-rata persen penghambatan. Data diambil dari rata-rata persen penghambatan masker wajah gel peel off yang diukur sebanyak 5 kali replikasi.

\section{KESIMPULAN}


Berdasarkan penelitian yang telah dilakukan, maka dapat diambil kesimpulan bahwa peningkatan konsentrasi gelatin dari $7,5 \%$ b/b (F1) sampai 12,5\% b/b (F3) akan meningkatkan daya lekat dan mempercepat waktu mengering. Peningkatan konsentrasi gelatin dari konsentrasi 7,5\% b/b (F1) ke 10\% $\mathrm{b} / \mathrm{b}$ (F2) tidak mempengaruhi daya sebar gel peel off tetapi memberikan pengaruh penurunan terhadap daya sebar gel pada konsentrasi gelatin $10 \% \mathrm{~b} / \mathrm{b}(\mathrm{F} 2)$ ke $12,5 \% \mathrm{~b} / \mathrm{b}$
(F3). Hasil uji aktivitas antioksidan menunjukkan rata-rata persen penghambatan pada konsentrasi gel peel off $100 \mathrm{mg} / \mathrm{mL}$ sebesar 9,101\% (F1); 12,469\% (F2); dan $15,109 \% \quad(\mathrm{~F} 3)$, sehingga peningkatan konsentrasi gelatin dari 7,5\% b/b (F1) sampai $12,5 \% \mathrm{~b} / \mathrm{b} \quad(\mathrm{F} 3)$ meningkatkan aktivitas antioksidan masker wajah gel peel off. Berdasarkan hasil uji sifat fisik dan aktivitas antioksidan menunjukkan bahwa formula yang direkomendasikan yaitu formula 2.

\section{Daftar Pustaka}

Barel, A. O., Paye, M., \& Maibach, H. I. (2009). Handbook of Cosmetic Science and Technology. Informa Healthcare USA (3rd Ed.). New York. https://doi.org/10.1001/archderm.138.9.1262-a

Febrianti, N., \& Wahyuningsih, R. (2016). Uji Aktivitas Antioksidan Ekstrak Etanol Berbagai Buah Tropik dengan Metode Ferrous Ion Chelating. Prosiding Symbion, 629-634.

Grace, X. F., C, D., K V, S., Afker, A., \& S, S. (2015). Preparation and Evaluation of Herbal Dentifrice. International Research Journal of Pharmacy, 6(8), 509-511. https://doi.org/10.7897/2230-8407.068102

Halimoon N. and Hasan M.H.A., 2010, Determination and evaluation of antioxidative activity in red dragon fruit (Hylocereus undatus) and green kiwi fruit (Actinidia deliciosa), American Journal of Applied Sciences, 7 (11), 1432-1438.

Lieberman, A. H., Rieger, M. M., \& Banker, S. G. (1998). Pharmaceutical Dosage Forms: Disperse System (Second Edi). New York.

Naibaho O.H., Yamlean P.V.Y. and Wiyono W., 2013, Pengaruh Basis Salep Terhadap Formulasi Sediaan Salep Ekstrak Daun Kemangi (Ocimum sanctum L.) Pada Kulit Punggung Kelinci yang Dibuat Infeksi Staphylococcus aureus, Jurnal Ilmiah FarmasiUNSRAT, 2 (2), 27-34.

Percival. (1998). Antioxidants. Clinical Nutrition Insights.

Prieto, J. M. (2012). Procedure : Preparation of DPPH Radical , and antioxidant scavenging assay. DPPH Microplate Protocol, 7-9.

Rahmawanty, D., Yulianti, N., \& Fitriana, M. (2015). Konsentrasi Gelatin Dan Gliserin Formulation and Evaluation Peel-Off Facial Mask Containing Quercetin With Variation Concentration of Gelatin and Gliserin. Media Farmasi, 12(1), 17-32.

Rebecca, O. P. S., Boyce, A. N., \& Chandran, S. (2010). Pigment Identification and Antioxidant Properties of Red Dragon Fruits. African Journal of Biotechnology, 9(10), 1450-1454. https://doi.org/10.5897/AJB09.1603 
Rowe, R., Sheskey, P., \& Quinn, M. (2009). Handbook of Pharmaceutical Excipients. Pharmaceutical Press (Sixth Ed.). London: Pharmaceutical Press. https://doi.org/10.1016/S0168-3659(01)00243-7

Sikora, E., Cieslik, E., \& Topolska, K. (2008). The Sources of Natural Antioxidants. Acta Sci. Pol., Technol. Ailment., 7(1), 5-17.

Suhartono, E. (2016). Toksisitas Oksigen Reaktif dan Antioksidan Di Bidang Kedokteran dan Kesehatan. Yogyakarta: Gosyen Publishing.

Suhery, W. N., \& Anggraini, N. (2016). Formulation and Evaluation of Peel-off Gel Masks from Red Rice Bran Extract with Various Kind of Bases, 9(12), 574-580.

Sulastri, A., \& Chaerunnisa, A. Y. (2017). Formulasi Masker Gel Peel Off Untuk Perawatan Kulit Wajah. Farmaka, 4(3), 1-12.

Syarifah, R. S., Mulyanti, D., \& Gadri, A. (2015). Formulasi Sediaan Masker Gel Peel-Off Ekstrak Daun Pepaya (Carica Papaya L.) sebagai Antijerawat dan Uji Aktivitasnya terhadap Bakteri Propionibacterium Acnes. Prosiding Penelitian SPeSIA Unisba 2015, 662-670.

Voigt, R. (1995). Buku Pelajaran Teknologi Farmasi. (S. Noerono, Ed.). Yogyakarta: Gajah Mada University Press.

Zhelsiana, D. A., Pangestuti, Y. S., Nabilla, F., Lestari, N. P., \& Wikantyasning, E. R. (2016). Formulasi dan Evaluasi Sifat Fisik Masker Gel Peel-Off Lempung Bentonite. The 4 Th Univesity Research Coloquium, 42-45. 
Pharmacon: Jurnal Farmasi Indonesia. Vol 15, No 2, (2018). ISSN 1411-4283 Available online at: http://journals.ums.ac.id/index.php/pharmacon 